\title{
ACTIVE TEACHING STRATEGIES IN HIGHER EDUCATION
}

\author{
Snježana Nevia Močinić, MSc \\ Department of Educational Sciences, \\ Juraj Dobrila University in Pula (Croatia) \\ e-mail: nmocinic@net.hr
}

\begin{abstract}
S u $\boldsymbol{m} \boldsymbol{m}$ ary
Requests for changes in teaching at all educational levels are normal consequences because of the rapid technological development and today's dynamic and complex reality. To improve educational achievements and students vocational training at the university, it is required to use alternative methods and procedures of teaching, blended in a combination of original strategies that promote active learning. This article indicates that the method of lecturing is the dominant one on the respondents' studies, but with a frequent use of guided conversations and discussions, which indicates a gradual reorganization of higher education. Results obtained in this paper do not demonstrate a continuing willingness of students towards intellectual and emotional involvement in the learning process and taking responsibility for learning on their own.
\end{abstract}

Key words: Higher Education, Teacher, Student, Teaching Strategies, Methods and Procedures, Active Learning and Teaching, Learning Outcomes, Acquisition of Skills and Abilities

\section{Introduction}

The consequence of the ever more important role of knowledge for the economic and social prosperity and of the focus on the active role of individuals in the building of his knowledge is the tendency to implement the new guidelines in the organisation of the teaching process where the teaching - learning relationship is more flexible, students are encouraged to take an active role in instruction processes and the teaching outcomes must include the acquisition of knowledge but also the gaining of competences. The goals of education defined through the learning outcomes or development of competences cannot be realised by sheer usage of traditional didactic strategies, approaches and methods, and more efficient form of teaching and learning are required. The goal of this paper is to direct the attention to strategies of teaching at the higher educational level, in particular the strategies which foster active learning and acquisition not only of new knowledge but also skills and attitudes in answer to the requirements of the rapid technological development and contemporary labour market. 


\section{Methods and procedures of teaching at higher-educational organisations}

Teaching has been changing under the influence of social changes which require the university education to answer the requirements of the dynamic and complex reality by organising a learning process able to train students to operate in professional practice (Apel, 2003, 32). The first step in the changes is to shift the emphasis from the teacher as knowledge provider to the student as the knowledge and skill acquirer. The student is no longer a passive recipient but becomes an active searcher in the process of knowledge building and application of knowledge and skills. This results in a more efficient education of young people, able to take their position in society. An American author, Prince (2004), considers that active learning can be achieved by any method of teaching which actively involves students into the process of authentic learning. Naturally, this mode of learning supersedes sheer memorizing and repetition of what the professor had said or done. The essence of such learning is in constant intellectual participation in the learning process. An Italian author, Zanchin (2002), also thinks that active teaching implies involvement of students in the teaching of curriculum contents, which fosters development of their procedural knowledge and its integration with declarative and metacognitive knowledge. Strategies of active teaching must possess the following characteristics:

- integrate thought and practical activities;

- enable varied learning styles;

- enable a methodologically correct teaching of curriculum contents regarding single disciplines;

- promote cognitive interaction with the others, whether adults or peers;

- develop higher-level cognitive processes;

- foster reflection and metacognitive activity;

- support readiness to carry out tasks and motivation to learn;

- enable observation and monitoring of students (e.g. their preknowledge and learning styles).

Lecture has so far remained the dominant form of academic teaching in spite of continued attacks, critiques and intentions to suppress it and replace it with more efficient methods and procedures (Apel, 2003, 27-37). In the effort to introduce changes in the approach to teaching at university, numerous researches have been carried out. These researches show that direct teaching is efficient in the transfer of knowledge, but is not sufficient for deeper understanding, problem solving, creative work and similar. (Terhart, 2001, Vizek Vidović, Vlahović Štetić, Rijavec, Miljković, 2003, Apel, 2003). Academic education is broadened by learning with the help of the new media, but personal interaction in social situations remains important in the learning process. New methods which will encourage students to participate in the teaching process, in a written or spoken form or actively, are therefore being researched. An Italian author, Chiari (2010), has proposed the 
following methods of active teaching: a) simulation methods: games involving simulation of imaginary situations and role play; b) discussion methods: discussion, case study, brainstorming and c) problem-based teaching. A German author, Mattes (2007) among active teaching methods includes dialogue, brainstorming, interactive lecturing, group work, pair work, experiment, role play, planned game, projectbased teaching plan, etc. Both these examples confirm not only the terminological heterogeneity of didactics at international level (Bežen, 2008), but also the lack of a systematisation of strategies, methods and procedures of academic teaching.

Authors Vizek Vidović, Vlahović-Štetić, Rijavec and Miljković (2003, 335375) do not use the term strategy, but a much narrower term: teaching methods or methods of teaching, defined as the learnt generalised form of behaviour which can be systematically applied in various teaching fields in order to facilitate and improve the learning outcome. Teaching techniques i.e. specific actions which are developed for the purpose of teaching a particular type of content, are an even narrower form of behaviour. The authors classify the teaching methods in accordance with the level of activation of students and teachers during teaching, and in accordance with the number of people taught. The extremes considering these two criteria are the maximum activity of teachers teaching in a numerous class vs. one student learning independently with occasional consultations with the teacher. Between these two extremes the authors included the following basic teaching forms: direct teaching, teaching based on guided discovery and discussion and independent learning regulated by feedback from the teacher on learning success. Direct teaching thus comprises the lecturing technique and the technique of display and modelling for the purpose of acquiring skills and procedural knowledge. The teaching based on guided discovery method comprises techniques of total and guided discovery, dialogue and discussion. The authors consider that independent learning requires development of skills for following the teaching process and skills of independent learning such as: organisation and elaboration of course-book texts, problem solving, revision, exercising, critical thinking and metacognitive skills. The above described overview of methods was amended by the authors $(2003,473-498)$ in the chapter of humanistic approach to education based on the following principles: studentoriented instruction, teacher as the facilitator, assistant and partner in the process of learning, contents is not the goal but the means to realize educational goals, learning is best encouraged in a cooperative environment. The best known forms of humanist education in practice are the open education, learning through research, learning through discovery and group discussion.

A term analogous to educational strategy, is mentioned by Poljak $(1985,144-$ 155), Jelavić (in Bežen et al., 1993, 94-128) and Bežen (2008, 155-157) as didactic systems. These comprise: catechetic, maieutic, heuristic, programmed, exemplary, problem-based and mentor instruction. systems are defined as strategic starting points regarding the role of the teacher, student, source of knowledge used in the organisation of teaching and the choice of teaching methods and procedures. Poljak (in Bežen, 2008, 157-158) describes didactic methods as modes of working in the teaching process including demonstration method, practical works, drawing, writing, reading and text comprehension, dialogue and oral presentation. A narrower term than the method is the teaching procedure, but in didactics it is not well defined and 
procedures can sometimes be found among methods, and sometimes among teaching systems or strategies. (Bežen, 2008, 160; Pletenac, 1993, 138). Bežen (2008, according to Pletenac, 1993) includes among teaching procedures the case method, mini-courses, microteaching, computer-aided teaching, Keller-Plan, brainstorming and workshop, and points to the terminological maze regarding the distinction between these basic didactic terms, not only among Croatian didacts, but also in the German-speaking countries. It is our opinion that the educational strategy, as a concept for achieving learning goals within a specific context, is defined by the teacher under the influence of personal and social factors, which makes it unpredictable. This means that didactic strategies cannot be classified. On the other hand, didactic methods, as modes of teaching within the instruction system, can hardly be separated from procedures and techniques of teaching because their meanings are often overlapping, especially in foreign literature. Some authors see the differences between these didactic terms in a greater complexity of the method as compared to single procedures and techniques. By joining various sources (Terhart, 2001, Apel, 2002, Bognar, Matijević, 2002, Vizek Vidović, Vlahović Štetić, Rijavec, Miljković, 2003, Baldacci, 2004, Mattes, 2007, Bežen, 2008) and extracting methods and procedures which encourage a higher level of student activity, we attempted to classify them in accordance with the size of the group, as such criterion often prevents the organisation of a better quality university instruction. Teaching large groups can be appropriate for lecturing accompanied by use of new media and involving students into conversation, solving short problems, summarize the taught contents and similar; for interactive lecture (students prepare in advance), demonstration (displaying everything that can be experienced in a perceptive manner) in combination with exercises to achieve skills, large-group debate (confronting opinions between two groups), discussion (taking and expressing personal standpoints on an exposed topic), problem-based teaching (learning by discovery), project teaching (coping with a starting situation and finding of a solution), integrated or interdisciplinary teaching (teaching of a unit across different curricular disciplines). Procedures adequate for active teaching in small groups comprise brainstorming (finding of a solution for a specific problem by gathering a list of ideas), small-group debate, simulation of virtual situations (natural processes, teaching situations, social relationships, etc.), role-playing, workshop, case study, microteaching, mini-courses, fieldwork, drama group, practical exercises. Teaching strategy is manifested therefore in a meaningful and purposeful choice and alternation of methods and procedures during the teaching to foster development of competences.

\section{Research methodology}

The starting point of this research was the theoretical background on active strategies of university teaching and learning. The goal of the empiric research was to examine the attitudes of students on the applied teaching methods and procedures at their university and on the preferred methods and procedures of teaching to improve learning. The research was joined by 360 students of the University of Pula, 139 of them being students of the Department of Educational Sciences, a total of 79 
of the Department for studies in Italian language, Department of Humanities and Department of Music, and 142 of the Department of Economics and Tourism students. A special survey questionnaire was created to gather information. The questionnaire a 4-level Likert-type scale: $1=$ Never, $2=$ Rarely, $3=$ Often, $4=$ Very often. Respondents' task was to assess how often didactic methods and procedures listed in the questionnaire were used, and, among these, select the five most efficient methods applicable to their learning. Quantitative and qualitative data analyses were applied to analyze the obtained information.

\section{Research results and discussion}

Table 1 shows the arithmetic mean and standard deviation regarding the assessment of use of each teaching method or procedure from the questionnaire. Judging from the obtained means (grades 1.56 to 1.93) role play, didactic game, field classes, trips and excursions, distance education, case study, brainstorming, workshop, programmed teaching, problem-based teaching and simulation. The next group of means (grades 2.02 to 2.48) pointes to a more frequent, but still inadequate, implementation of project teaching, debate in small and large groups, guided practical exercises, showing video material, demonstration with exercising and interactive lesson.

According to the respondents' statements, discussion, guided conversation and frontal teaching are relatively often used (grade 2.70 to 2.84). The obtained means and high standard deviations $(\mathrm{M}=2.58, \mathrm{SD}=1.059)$ lead to the conclusion that the method of integrated or interdisciplinary teaching is frequently used in some departments, while rarely or never in others. It can also be seen that the methods and procedures which prompt students to cooperate and take an active role in teaching are used insufficiently. Frontal teaching is still predominant, even though this traditional form of teaching is not adequate to modern life circumstances. Namely, it requires learning based on listening, watching and reiterating and mostly implies a one-way communication and activities linked to printed media. Such teaching methods do not incite intellectual and emotional involvement of students in the cognitive process, which is essential to active learning. Also noted was a step forward towards a more frequent use of the conversation method, which has a positive impact on learning, supports efforts in creating new notions, allows examination and criticism of other people's opinions, provides material for a later personal reflective thought (Desforges, 2001, Terhart, 2001), but is at the same time an extremely demanding method as it calls for excellent knowledge of the topic, high communication competence and control of emotions from all participants, otherwise there is the risk of losing the thread or redirecting it to secondary topics (Vizek Vidović et al., 2003). We suppose that some of the reasons of insufficient usage of active teaching methods and procedures are a strong impact of educational tradition, difficulties caused by working in large groups, lack of time and material, uneasiness caused by application of new didactic procedures, fear that students would not participate, etc. 
Table 1: Overview of respondents' opinions on the applied teaching methods and procedures

\begin{tabular}{|c|l|c|c|c|}
\hline $\begin{array}{l}\text { Item } \\
\text { No. }\end{array}$ & \multicolumn{1}{|c|}{ Methods and procedures of teaching } & $\mathbf{N}$ & $\mathbf{M}$ & $\mathbf{S D}$ \\
\hline 1. & Frontal teaching & 359 & 2.84 & .93 \\
\hline 2. & Interactive lesson & 360 & 2.48 & .77 \\
\hline 3. & Demonstrations with exercising & 360 & 2.43 & .80 \\
\hline 4. & Guided conversation & 360 & 2.80 & .71 \\
\hline 5. & $\begin{array}{l}\text { Discussion (expression of personal } \\
\text { attitudes) }\end{array}$ & 360 & 2.70 & .72 \\
\hline 6. & Debate (attitudes of two or more groups) & 360 & 2.31 & .82 \\
\hline 7. & Debate in small groups & 360 & 2.15 & .76 \\
\hline 8. & Showing video material & 359 & 2.27 & .79 \\
\hline 9. & Guided practical exercises & 360 & 2.25 & .78 \\
\hline 10. & Brainstorming & 360 & 1.81 & .74 \\
\hline 11. & Simulation & 360 & 2.02 & .73 \\
\hline 12. & Programmed teaching & 360 & 1.90 & .78 \\
\hline 13. & Distance education & 360 & 1.70 & .94 \\
\hline 14. & Integrated or interdisciplinary teaching & 360 & 2.58 & 1.05 \\
\hline 15. & Problem-based teaching & 359 & 1.93 & .68 \\
\hline 16. & Project teaching & 359 & 2.11 & .87 \\
\hline 17. & Field classes, trips and excursions & 360 & 1.69 & .76 \\
\hline 18. & Workshop & 360 & 1.89 & .83 \\
\hline 19. & Role play & 360 & 1.56 & .72 \\
\hline 20. & Didactic game & 359 & 1.62 & .72 \\
\hline 21. & Case study & 360 & 1.75 & .77 \\
\hline
\end{tabular}

When faced with a host of differently motivated and intellectually disposed young people, it may be difficult to select a teaching method that would satisfy everyone. During lessons students want to be comfortable, take an active role, successfully conquer teaching content and build their personality. Table 2 . shows the frequency of didactic method and procedure the respondents selected as successful in inciting academic learning. In line with the importance of practical experience to achieve professional competence, the first place (55.99\% of votes) was taken by field classes, trips and excursions, and the third place ( $46.11 \%$ of votes) by workshop. The second and fourth places were taken by discussion and debate respectively, the fifth place, with the same percentage of votes (34.73\%), was taken by interactive lesson and demonstration with exercising, the sixth place by guided conversation (29.64\%of votes), and the eighth by project teaching (23.05\% of votes). The advantage of these methods is the active involvement of students in the teaching process, leading to more successful learning. A rather high position in the students' ranking was taken by showing video and audio material $(28.44 \%$ of votes), which indicates that more appealing and attractive content should be introduced in teaching, thus increasing attention and concentration of students during lessons. The ninth place taken by frontal teaching is quite reassuring - it 
points to unwillingness of students to take over the responsibility for personal learning because only in teaching promoting active learning students become the key subject of activity and cannot avoid the burden of responsibility. Active teaching methods imply a drastic change of educational practice, which can cause negative reaction of those students who consider that professors should give lectures and not make them learn on their own.

Table 2: Overview of respondents' opinions on the most efficient teaching methods and procedures

\begin{tabular}{|l|l|c|c|c|c|}
\hline \multirow{2}{*}{$\begin{array}{l}\text { Item } \\
\text { No. }\end{array}$} & \multicolumn{1}{|c|}{$\begin{array}{c}\text { Methods and procedures of } \\
\text { teaching }\end{array}$} & \multirow{2}{*}{$\mathbf{N}$} & \multicolumn{3}{|c|}{ Preferences of students } \\
\cline { 4 - 6 } & \multicolumn{1}{|c|}{$\mathbf{f}$} & $\mathbf{\%}$ & rank \\
\hline 1. & Frontal teaching & 334 & 64 & 19,16 & 9. \\
\hline 2. & Interactive lesson & 334 & 116 & 34,73 & 5. \\
\hline 3. & Demonstrations with exercising & 334 & 116 & 34,73 & 5. \\
\hline 4. & Guided conversation & 334 & 99 & 29,64 & 6. \\
\hline 5. & $\begin{array}{l}\text { Discussion (expression of personal } \\
\text { attitudes) }\end{array}$ & 334 & 167 & 50,00 & 2. \\
\hline 6. & $\begin{array}{l}\text { Debate (attitudes of two or more } \\
\text { groups) }\end{array}$ & 334 & 121 & 36,23 & 4. \\
\hline 7. & Debate in small groups & 334 & 45 & 13,47 & 13. \\
\hline 8. & Showing video material & 334 & 95 & 28,44 & 7. \\
\hline 9. & Guided practical exercises & 334 & 43 & 12,87 & 14. \\
\hline 10. & Brainstorming & 334 & 53 & 15,87 & 11. \\
\hline 11. & Simulation & 334 & 44 & 13,17 & 14. \\
\hline 12. & Programmed teaching & 334 & 26 & 7,78 & 18. \\
\hline 13. & Distance education & 334 & 44 & 13,17 & 14. \\
\hline 14. & Integrated or interdisciplinary & 334 & 40 & 11,98 & 15. \\
\hline & teaching & 334 & 52 & 15,57 & 12. \\
\hline 15. & Problem-based teaching & 334 & 77 & 23,05 & 8. \\
\hline 16. & Project teaching & 334 & 187 & 55,99 & 1. \\
\hline 17. & Field classes, trips and excursions & 334 & 154 & 46,11 & 3. \\
\hline 18. & Workshop & 334 & 39 & 11,68 & 16. \\
\hline 19. & Role play & 334 & 29 & 8,68 & 17. \\
\hline 20. & Didactic game & 334 & 58 & 17,36 & 10. \\
\hline 21. & Case study & & & \\
\hline
\end{tabular}

Unexpectedly low positions on the scale of efficient teaching methods and procedures were taken by role play, integrated or interdisciplinary teaching, guided practical exercises, debate in small groups, simulation, problem-based teaching, brainstorming, even though these are included among active methods of teaching by eminent experts (Terhart, 2001, Bognar, Matijević, 2002, Vizek Vidović, Vlahović Štetić, Rijavec, Miljković, 2003, Mattes, 2007, Bežen, 2008). The reason could be found in the fact that students are unaware of the advantages of single methods and procedures which, according to their statements, are rarely or never implemented in their studies. The bottom of the scale is taken by distance education, probably 
because it requires use of innovative opportunities offered by IT, but is still rarely used in teaching, and programmed teaching whose preparation requires great expenditure and is not cost-effective as the included teaching contents rapidly become obsolete.

\section{Conclusion}

Turbulent social processes require a flexible and dynamic university ready to change and accept the fact that it is no longer the exclusive place where information is gathered and knowledge acquired. Any demand for a change involves innovative approaches to teaching and learning as a response to the challenges set by new media and learning theories, such as cognitivism and social constructivism. An especially important role is played by active teaching methods and procedures which recognize different needs of individual students, asking them to assume liability for personal learning and promoting critical thinking and independent learning. The leader of these changes is the teacher who must be able to implement various different teaching methods and procedures and to alternate them strategically encouraging creativity, problem solving, experience-based learning and metacognition. The fact that working methods and procedures, such as guided conversation, participation of student in discussions and debates, are being used on a more frequent basis, indicates a positive movement in the reorganisation of university teaching process. Nevertheless, our research indicates the still predominant position of the oral lecture method and the need for a more varied usage of teaching methods and procedures enabling students to be more active and to assume greater liability in their own educational process.

\section{Bibliography}

1. Apel, H. J., (2003), Predavanje, uvod u akademski oblik poučavanja, Zagreb: EruditA

2. Baldacci, (a cura di), (2004), I modelli della didattica, Roma: Carocci editore

3. Bežen, A., (2008), Metodika, znanost o poučavanju nastavnog predmeta, Zagreb: Učiteljski fakultet i Profil

4. Bežen, A., i dr., (1993), Osnove didaktike, Zagreb: Školske novine

5. Bognar, L., Matijević, M., (2002), Didaktika, Zagreb: Školska knjiga

6. Chiari, F., (2010), I Metodi Attivi ed i giochi di simulazione, na mrežnoj stranici http://provvbo.scuole.bo.it/cliccando/cap13.pdf Educa

7. Desforges, Ch., (2001), Uspješno učenje i poučavanje. Psihologijski pristupi, Zagreb:

8. Jelavić, F., u Bežen i dr., Osnove didaktike, Zagreb: Školske novine

9. Laeng, M., (1994), Enciclopedia pedagogica, vol. VI, Brescia: Editrice La Scuola

10. Mattes, W., (2007), Nastavne metode. 75 kompaktnih pregleda za nastavnike $i$ učenike, Zagreb: Naklada Ljevak

11. Moscato, M., T., (2008), Diventare insegnanti. Verso una teoria dell'insegnamento, Brescia: Edizioni La Scuola 
12. Pletenac, V., (1993), u Bežen i dr., Osnove didaktike, Zagreb: Školske novine

13. Poljak, V., (1984), Didaktika, Zagreb: Školska knjiga

14. Prince, M., (2004), Does active learning work? u A review of research. Journal of Engineering Education, 93 (3), 223-231

15. Terhart, E. (2001), Metode poučavanja i učenja, Zagreb: Educa

16. Vizek Vidović V., Vlahović-Štetić V., Rijavec, M., Miljković D. (2003), Psihologija obrazovanja, Zagreb: IEP-VERN

17. Zanchin, M. R., (2002), Le strategie attive, u AA.VV., Le interazioni educative, Roma: Armando

Metodički obzori 7(2012)2

Preliminary announcement UDK: $37.02: 378.6$

Primljeno: 13. 11. 2010.

\title{
STRATEGIJE AKTIVNOG POUČAVANJA U VISOKOŠKOLSKOJ NASTAVI
}

\author{
Mr. sc. Snježana Nevia Močinić \\ Odjel za odgojne i obrazovne znanosti \\ Sveučilište Jurja Dobrile u Puli (Hrvatska) \\ e-mail: nmocinic@net.hr
}

\begin{abstract}
Sažetak
Zahtjevi za promjenama u nastavi na svim obrazovnim razinama normalna su posljedica naglog tehnološkog razvoja i današnje dinamične i složene stvarnosti. Za poboljšanje obrazovnih postignuća i profesionalno osposobljavanje studenata na sveučilišnim studijima, nužna je primjena alternativnih metoda i postupaka poučavanja, kombiniranih u splet originalnih strategija koje promoviraju aktivno učenje. Iz ovog istraživanja proizlazi da je metoda usmenog izlaganja dominantna na studijima ispitanika, ali uz dosta često korištenje vođenog razgovora i diskusije što ukazuje na postepenu reorganizaciju visokoškolske nastave. Dobiveni rezultati ne pokazuju uvijek spremnost studenata na intelektualno $\mathrm{i}$ emocionalno uključivanje u proces učenja i preuzimanje odgovornosti za vlastito učenje.

Ključne riječi: visokoškolska nastava, nastavnik, student, strategije, metode $i$ postupci poučavanja, aktivno učenje $i$ poučavanje, ishodi učenja, stjecanje sposobnosti $i$ vještina
\end{abstract}

